\title{
Effect of oestradiol and tamoxifen on the testosterone response in male rats to a single injection of hCG
}

\author{
Y. M. Hodgson, G. Urquhart and D. M. de Kretser \\ Department of Anatomy, Monash University, Clayton, Victoria 3168, Australia
}

\begin{abstract}
Summary. A single s.c. injection of hCG (100 i.u.) produced a biphasic serum testosterone response in adult male rats, peaks being noted at $2 \mathrm{~h}(24 \mathrm{ng} / \mathrm{ml})$ and 3 days $(16 \mathrm{ng} / \mathrm{ml})$. The levels fell to control during the intervening interval $(8 \mathrm{ng} / \mathrm{ml})$, although there were elevated levels of serum hCG. Maintenance of high oestradiol levels by a s.c. injection of $50 \mu \mathrm{g}$ oestradiol benzoate given on Day 2 after the initial hCG injection failed to prolong the refractory period and the secondary peak of testosterone (16 $\mathrm{ng} / \mathrm{ml}$ ) occurred on Day 3. Administration of the antioestrogen, tamoxifen ( $2 \mathrm{mg}$ or 3 $\mu \mathrm{g}), 24 \mathrm{~h}$ before or simultaneously with $\mathrm{hCG}$ did not prevent testicular refractoriness in vivo because serum testosterone levels still declined after $2 \mathrm{~h}$ to reach a nadir at 2 days.

The basal in-vitro testosterone production by decapsulated testes from animals injected with hCG was enhanced at $2 \mathrm{~h}$. Stimulation by hCG increased the amount of testosterone produced ( $\times 1.5$ that in controls). By $12 \mathrm{~h}$ basal production decreased and there was no further increment in testosterone in the presence of hCG. This refractoriness to further hCG stimulation prevailed until Day 3, but the total production of testosterone fell so that at $24 \mathrm{~h}$ and 2 days testes were producing basal amounts of testosterone. Testes recovered from refractoriness at 4 and 5 days, when basal and stimulated testosterone production were greater than in controls. Injection of $50 \mu \mathrm{g}$ oestradiol benzoate at 2 days did not prolong the in-vitro refractory period and 2 $\mathrm{mg}$ or $3 \mu \mathrm{g}$ tamoxifen had no effect on the in-vitro steroidogenic activity, since testes were still refractory to further hCG stimulation from $12 \mathrm{~h}$ to 3 days. The results of the present study do not support the hypothesis that oestradiol is involved in the hCGinduced refractoriness of the Leydig cell. The nadir between the peaks of serum testosterone in vivo corresponds to the period during which the testis is refractory to invitro stimulation by $\mathrm{hCG}$.
\end{abstract}

\section{Introduction}

A single injection of 100 i.u. hCG produced a biphasic response of serum testosterone in the adult male rat with maximum testosterone concentrations $2 \mathrm{~h}$ and 3 days after administration (Haour \& Saez, 1977; Hodgson \& de Kretser, 1982). Between these times, serum testosterone declined to control levels, a decrease which is enigmatic considering the elevated levels of serum hCG which were present (Hodgson \& de Kretser, 1982) and suggests a refractoriness of the Leydig cell to stimulation. In confirmation of this view, a second injection of hCG was ineffective in modifying testosterone levels for approximately 3 days (Haour \& Saez, 1978). Equivalent studies in man have also indicated an in-vivo refractoriness, since quantitatively similar testosterone responses were observed after single and 3 daily injections of hCG (Smals, Pieters, Drayer, Benraad \& Kloppenborg, 1979). Estimation of plasma concentrations of testosterone and its precursors in men 
showed an increase in progesterone and 17 1 -hydroxyprogesterone concomitant with the falling concentration of testosterone between $2 \mathrm{~h}$ and 3 days, indicating a lesion in the steroidogenic pathway at the $17 \alpha$-hydroxylase and $C_{17-20}$ lyase enzymes (Forest, Lecoq \& Saez, 1979). Similar lesions have been reported for suspensions of purified rat Leydig cells 2 and 3 days after hCG treatment (Tsuruhara, Dufau, Cigorraga \& Catt, 1977; Cigorraga, Dufau \& Catt, 1978). The resemblance of these enzymic lesions to those observed in the mouse testis after the chronic administration of oestradiol (Samuels, Bussmann, Matsumoto \& Huseby, 1964) led to the hypothesis that the rise in oestradiol after hCG stimulation was responsible for the refractory period noted in vitro (Tsuruhara et al., 1977; Forest et al., 1979; Cigorraga, Sorrell, Bator, Catt \& Dufau, 1980).

This study examines the temporal relationships between the in-vivo and in-vitro refractory periods seen after single large injections of hCG and further explores the role of oestradiol in this phenomenon. To examine this hypothesis exogenous oestradiol was administered in an effort to prolong the nadir between the peaks of testosterone. In addition, the antioestrogen, tamoxifen, was used to test the role of the oestradiol receptor in the development of Leydig cell refractoriness.

\section{Materials and Methods}

Sprague-Dawley rats aged $80-90$ days were injected with saline $(9 \mathrm{~g} \mathrm{NaCl} / \mathrm{l})$, hCG (Pregnyl: Organon) and oestradiol benzoate (Intervet Pty Ltd, Australia) or tamoxifen (Nolvadex base, courtesy of I.C.I. Macclesfield, U.K.) according to the design described below. The rats were killed by decapitation at different times after the injections, blood samples were collected and the serum was stored at $-20^{\circ} \mathrm{C}$ until assayed for testosterone by radioimmunoassay. The testes from each animal were removed, decapsulated and placed in glass vials containing $2 \mathrm{ml}$ Krebs-Ringer bicarbonate buffer (for composition see Sharpe \& Fraser, 1980a) with $2 \mathrm{mg}$ glucose/ml or buffer plus $700 \mathrm{mi} . \mathrm{u} . / \mathrm{hCG} \mathrm{ml}$, a dose shown previously to result in maximal stimulation (Risbridger, Robertson \& de Kretser, 1982). Testes were incubated at $34^{\circ} \mathrm{C}$ for $4 \mathrm{~h}$ in a shaking water bath according to methods previously described (de Kretser, Sharpe \& Swanston, 1979), the media were removed and centrifuged at $2000 \mathrm{~g}$ for $20 \mathrm{~min}$ to remove cell debris. The supernatant was then diluted with distilled water and assayed directly for testosterone by radioimmunoassay.

\section{Experiments}

Experiment I. The rats received (a) a s.c. injection of 100 i.u. hCG $(\mathrm{N}=50)$; (b) a s.c. injection of 100 i.u. hCG followed 2 days later by a s.c. injection of $50 \mu \mathrm{g}$ oestradiol benzoate in peanut oil $(\mathrm{N}=35)$; (c) saline and then $50 \mu \mathrm{g}$ oestradiol benzoate after 2 days $(\mathrm{N}=35)$; (d) saline and peanut oil only $(\mathrm{N}=55$, controls). To determine intratesticular oestradiol levels in rats injected with oestradiol benzoate, the testes were removed and stored at $-20^{\circ} \mathrm{C}$ until assayed for oestradiol when they were homogenized in Tris- $\mathrm{MgCl}_{2}$ buffer $(\mathrm{pH} \mathrm{7.2)}$ before ether extraction.

Experiment II. Rats received a s.c. injection of $2 \mathrm{mg}$ tamoxifen in peanut oil $24 \mathrm{~h}$ before or simultaneously with 100 i.u. hCG. Control rats received vehicle or tamoxifen only.

Experiment III. The design of this experiment followed that of Cigorraga et al. (1980). The rats received concomitantly a s.c. injection of $1.5 \mu \mathrm{g}$ tamoxifen and an i.m. injection of $1.5 \mu \mathrm{g}$ tamoxifen in saline with 100 i.u. hCG. Control animals received saline injections or tamoxifen $(1.5 \mu \mathrm{g} \mathrm{s.c.} \mathrm{or}$ $1.5 \mu \mathrm{g}$ i.m.) only.

\section{Hormone assays}

Testosterone. Serum concentrations were measured by the radioimmunoassay described by Risbridger, Kerr \& de Kretser (1981) using an antiserum raised in sheep against testosterone-3- 
carboxy-methyl-oxime conjugated to bovine serum albumin: $5 \alpha$-dihydroxytestosterone showed a $98 \%$ cross-reactivity but because the contribution of this androgen in the rat is minor, the serum values are referred to as testosterone. The intra-assay coefficient of variation was $7-9 \%$ and the inter-assay coefficient of variation was $16-17 \%$. The sensitivity of the assay was $5 \mathrm{pg} / 100 \mu \mathrm{l}$.

Oestradiol. Oestradiol in testicular extracts was measured by the method of Pomerantz (1979). Briefly, testicular homogenates were extracted with ether and the ether extracts were dried under nitrogen. The residue was dissolved in a mixture of chloroform, heptane, methanol and water ( $500: 500: 75: 3$ by vol.) and chromatographed on Sephadex LH-20 columns in the same solution. A portion of the eluate was used to determine recovery and the remainder assayed in a radioimmunoassay using [ ${ }^{125} \mathrm{I}$ ]oestradiol (sp. act. $7.4 \mathrm{TBq} / \mathrm{mmol}$ : Amersham International, U.K.) and an antiserum to oestradiol kindly provided by $\mathrm{Dr} R$. Swerdloff. The antiserum was raised in rabbits and showed $35 \%$ cross-reactivity with oestrone. The cross-reactivity of the antiserum for testosterone was $<0.2 \%$ and testosterone was separated from oestradiol by the chromatographic steps. Separation of bound from free oestradiol after a 16 -h incubation at $4^{\circ} \mathrm{C}$ was achieved using $1 \%$ charcoal. The intra- and inter-assay coefficients of variation were $6 \%$ and $14 \%$ respectively. The sensitivity of this assay was $0.25 \mathrm{pg} / 100 \mu \mathrm{l}$.

\section{Statistical analysis}

Duncan's multiple range test in conjunction with analysis of variance or a Student's $t$ test was used to test the significance of changes in testosterone levels. Results are expressed as mean \pm s.e.m.

\section{Results}

Effect of oestradiol benzoate on the serum testosterone response to $h C G$

Injection of 100 i.u. hCG produced a significant increase in serum testosterone at $2 \mathrm{~h}$ $(24.4 \pm 3 \cdot 2 \mathrm{ng} / \mathrm{ml}$ ) compared with $6 \cdot 2 \pm 1 \cdot 2 \mathrm{ng} / \mathrm{ml}$ for controls (Text-fig. 1$)$, followed by a decline to control levels of $8.1 \pm 1.0 \mathrm{ng} / \mathrm{ml}$ at 2 days. Rats receiving hCG only showed a second increase of

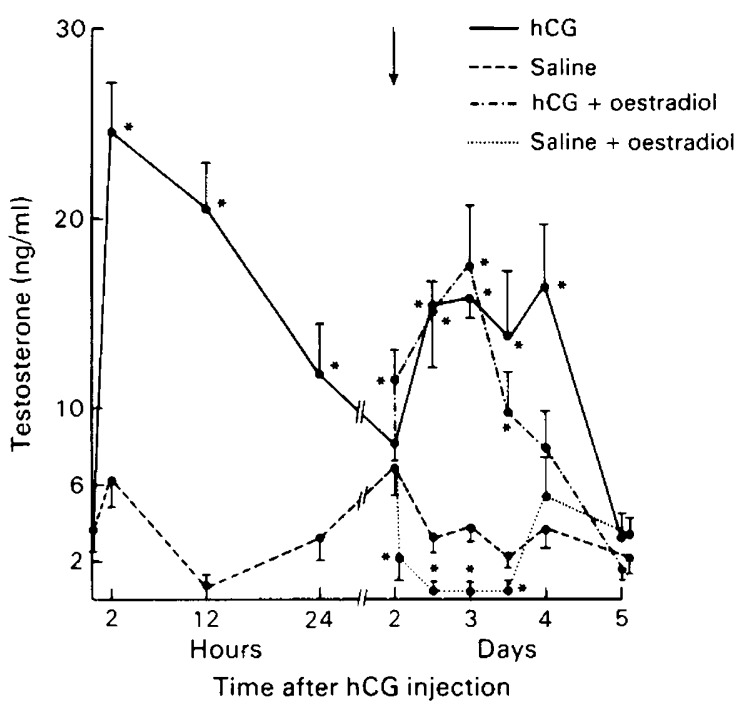

Text-fig. 1. The effect of $50 \mu \mathrm{g}$ oestradiol benzoate (arrow) on the serum testosterone response of rats after a single injection of hCG. Each point represents the mean \pm s.e.m. of 5 animals. *Values significantly different $(P<0.05)$ from that of the saline-treated controls at that time. 
testosterone at 2.5 days. Levels remained high until 4 days $(13.7-16.5 \mathrm{ng} / \mathrm{ml})$ and then returned to basal concentrations at 5 days. A s.c. injection of $50 \mu \mathrm{g}$ oestradiol benzoate $48 \mathrm{~h}$ after hCG did not inhibit the secondary rise of testosterone which reached peak levels of $15.6 \pm 3.2 \mathrm{ng} / \mathrm{ml}$ at 2.5 days (Text-fig. 1). The serum testosterone levels at 3 days $(16 \cdot 6 \pm 3 \cdot 2 \mathrm{ng} / \mathrm{ml})$ did not differ from those in rats injected with hCG but not with oestradiol benzoate $(15.8 \pm 1.7 \mathrm{ng} / \mathrm{ml})$. Oestradiol benzoate alone caused a decrease in the baseline levels of serum testosterone for 1.5 days $(0.45 \pm 0.02 \mathrm{ng} / \mathrm{ml}$ compared with $2 \cdot 9 \pm 0 \cdot 3 \mathrm{ng} / \mathrm{ml}$ ).

Oestradiol benzoate caused a 29-fold increase in testicular oestradiol levels $2 \mathrm{~h}$ after administration. The levels declined slowly (Table 1$)$ to remain significantly elevated $(P<0.05)$ at $72 \mathrm{~h}$ after the injection.

Table 1. Intratesticular oestradiol levels (pg/testis) in control and oestradiol-treated rats after a single injection of $50 \mu \mathrm{g}$ oestradiol benzoate

\begin{tabular}{lccccc}
\hline & \multicolumn{5}{c}{ Time after injection } \\
\cline { 2 - 6 } & $2 \mathrm{~h}$ & $12 \mathrm{~h}$ & $24 \mathrm{~h}$ & $48 \mathrm{~h}$ & $72 \mathrm{~h}$ \\
\hline Saline & $59 \cdot 7 \pm 8 \cdot 7$ & $35 \cdot 0 \pm 5 \cdot 1$ & $51 \cdot 5 \pm 7 \cdot 9$ & $34 \cdot 4 \pm 3 \cdot 3$ & $30 \cdot 8 \pm 4 \cdot 2$ \\
$\begin{array}{l}\text { Oestradiol benzoate } \\
(50 \mu \mathrm{g})\end{array}$ & $1726 \pm 401^{*}$ & $1245 \pm 184^{*}$ & $839 \pm 137^{*}$ & $516 \pm 157^{*}$ & $151 \pm 39^{* *}$ \\
\hline
\end{tabular}

Values represent mean \pm s.e.m. for $n=5$.

${ }^{*} P<0.01,{ }^{* *} P<0.05$ compared to corresponding value for saline-treated rats.

\section{Effect of oestradiol benzoate on the in-vitro production of testosterone}

The average basal and stimulated production of testosterone by control rat testes was $64.5 \pm 8.1$ and $365.9 \pm 62.1 \mathrm{ng} /$ testis/4 h respectively. The coefficients of variation, calculated from a total of 160 testes, were $6.3 \%$ for basal production and $21.8 \%$ for stimulated production. The quantity of testosterone secreted following maximal hCG stimulation varied considerably from one time point to another. To minimize these differences and to aid interpretation of the data, the results were expressed as a percentage of the stimulated amount of testosterone secreted by testes from control animals ( $\%$ stimulated control).

The basal production of testosterone in vitro was enhanced $2 \mathrm{~h}$ after the hCG injection and the levels were $93.6 \%(342 \pm 48 \mathrm{ng} /$ testis $/ 4 \mathrm{~h})$ those of stimulated controls. Addition of $700 \mathrm{mi} . \mathrm{u}$. $\mathrm{hCG} / \mathrm{ml}$ to the incubation medium produced a further increase in testosterone production to give levels equivalent to $150 \%$ those of saline-treated stimulated controls (Text-fig. $2 \mathrm{a}$ ). By $12 \mathrm{~h}$ the basal production of testosterone decreased, but was still greater $(P<0.05)$ than that produced by saline controls. At this time, there was no further increment in testosterone production if $\mathrm{hCG}$ was added to the buffer. This period of refractoriness to further stimulation prevailed until 3 days but the total production of testosterone declined and, at $24 \mathrm{~h}$ and 2 days, the testes were secreting levels of testosterone equivalent to those achieved basally in saline-treated controls. In keeping with the invivo pattern of serum testosterone response, the production of testosterone increased at 2.5 and 3 days although testes were still refractory to hCG stimulation in vitro. Testes recovered from refractoriness at $3 \cdot 5$ days and from this time until 5 days the basal and stimulated testosterone secretion from hCG-treated animals was significantly higher than that from saline-treated controls $(P<0.05$; Text-fig. 2a).

Oestradiol benzoate had an inhibitory effect on basal and stimulated testosterone secretion of control testes (not injected with hCG). Basal production was significantly reduced at 2.5 and 3 days $(30.4 \pm 4.4$ and $19.4 \pm 2.4 \mathrm{ng} /$ testis $/ 4 \mathrm{~h}$ compared with $57.4 \pm 5.2$ and $97.0 \pm 10.0 \mathrm{ng} / \mathrm{testis} / 4 \mathrm{~h}$ for saline controls $(P<0.05)$ ) and returned to control levels at $3.5,4$ and 5 days (Text-fig. 2b). Similarly, stimulated levels of testosterone were significantly depressed at 2.5 and 3 days 

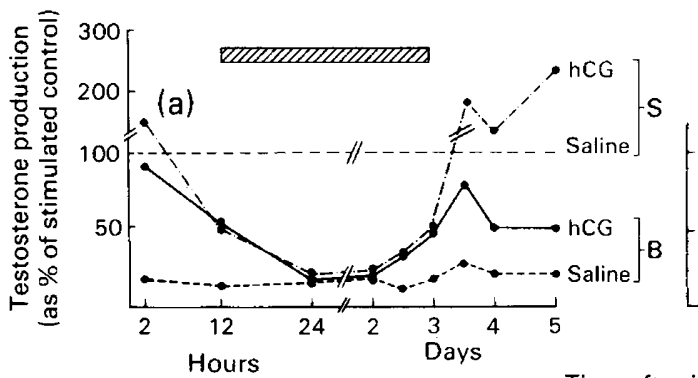

Time after injection

(b)

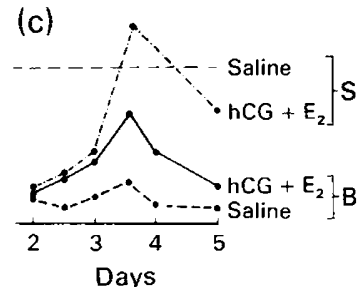

Text-fig. 2. The effect of oestradiol benzoate on the in-vitro steroidogenic activity of rat testes after a single injection of (a) hCG, (b) oestradiol benzoate ( $\left.E_{2}\right)$, and (c) hCG and oestradiol benzoate. Each point represents the mean of 5 animals. In (a) the refractory period is indicated by the hatched bar. $\mathrm{S}=$ stimulated; $\mathrm{B}=$ basal.

$(133.0 \pm 24.6$ and $131.2 \pm 30.6 \mathrm{ng} /$ testis $/ 4 \mathrm{~h})$ compared with testes from rats receiving hCG only $(493.6 \pm 81.4$ and $596.4 \pm 85.0 \mathrm{ng} /$ testis $/ 4 \mathrm{~h}, P<0.05$; Text-fig. 2a). Steroidogenic capacity returned to control levels at 3.5 and 4 days, but stimulated testosterone production was decreased at 5 days. Injection of oestradiol benzoate 2 days after 100 i.u. hCG did not modify the in-vitro steroidogenic activity, although the amount of testosterone produced in the presence of hCG was lower than in saline-treated controls from 3.5 to 5 days (Text-fig. 2c). Animals treated with hCG only showed an enhanced steroidogenic capacity at this time (Text-fig. 2a).
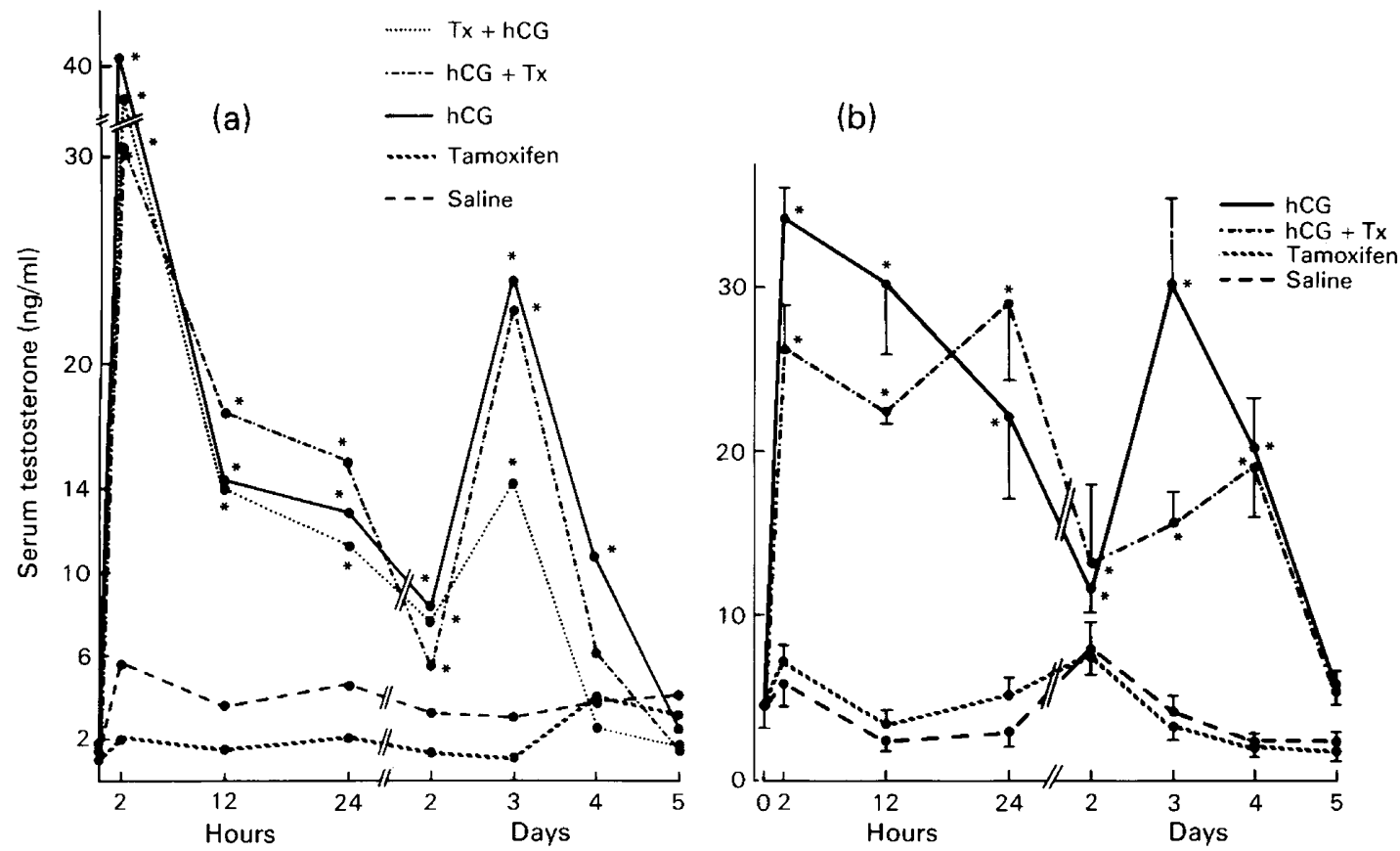

Time after injection

Text-fig. 3. The effect of tamoxifen (Tx; a, $2 \mathrm{mg} ; \mathrm{b}, 3 \mu \mathrm{g}$ ) on the serum testosterone response in rats after hCG injection. $\mathrm{Tx}+\mathrm{hCG}=\operatorname{tamoxifen}$ given $24 \mathrm{~h}$ before $\mathrm{hCG} ; \mathrm{hCG}+\mathrm{Tx}=\mathrm{hCG}$ and tamoxifen given simultaneously. Points represent the mean of 5 animals; some s.e.m. bars have been omitted for clarity. ${ }^{*}$ Values significantly different $(P<0.05)$ from that of the salinetreated controls at that time. 
Effect of tamoxifen on the serum testosterone response to $h C G$

Administration of $2 \mathrm{mg}$ tamoxifen $24 \mathrm{~h}$ before or at the same time as a single injection of $100 \mathrm{i} . \mathrm{u}$. hCG had no effect on the serum testosterone response to hCG (Text-fig. 3a). In all groups, serum testosterone was significantly increased $2 \mathrm{~h}$ after hCG stimulation with peak values of $30-42 \mathrm{ng} / \mathrm{ml}$. Values then declined to a nadir at 2 days but the levels were still significantly higher than in rats receiving saline or tamoxifen alone. At 3 days a second rise in serum testosterone occurred in all groups injected with hCG, but the peak values recorded in the group treated with tamoxifen before hCG were significantly less than those seen in rats injected with hCG alone (14.3 \pm 1.0 compared with $24.1 \pm 2.3 \mathrm{ng} / \mathrm{ml} ; P<0.05$; Text-fig. 3a). Serum testosterone levels returned to control levels at 5 days.

When a lower dose of $3 \mu \mathrm{g}$ tamoxifen was used, no modification of the serum testosterone response was seen (Text-fig. 3b). The decline in serum testosterone normally seen after the first peak was not prevented and the testosterone concentration fell to control levels on Day 2 . There was a second response at 3 and 4 days but the peak testosterone values seen in rats treated with tamoxifen and hCG were significantly less than those measured in rats injected with hCG alone $(19 \cdot 1 \pm 3 \cdot 7$ compared with $30 \cdot 1 \pm 6 \cdot 3 \mathrm{ng} / \mathrm{ml} ; P<0.05$; Text-fig. $3 \mathrm{~b})$. Serum testosterone levels in both groups fell to control values on Day 5 .

\section{The effect of tamoxifen on the in-vitro production of testosterone}

Administration of tamoxifen alone ( $2 \mathrm{mg}$ or $3 \mu \mathrm{g}$ ) had no effect on the in-vitro steroidogenic activity (Text-figs $4 \mathrm{a} \&$ b). Because Exps II and III were performed at a different time from Exp. I, the in-vitro steroidogenic activity seen after a single injection of hCG was repeated (Text-fig. 5a). The pattern was similar to that in Exp. I (Text-fig. 2a) except at 3 days when, for unknown reasons, the basal and stimulated testosterone production was higher. In animals killed at $2 \mathrm{~h}$, basal $(767 \pm 48 \mathrm{ng} /$ testis $/ 4 \mathrm{~h})$ and stimulated $(808 \pm 14 \mathrm{ng} /$ testis $/ 4 \mathrm{~h})$ testosterone production by testes from rats given $2 \mathrm{mg}$ tamoxifen $24 \mathrm{~h}$ before hCG were significantly greater $(P<0.01)$ than stimulated secretion of testes from control rats treated with saline $(249.2 \pm 22.4 \mathrm{ng} /$ testis/4 h $)$ and from rats treated with hCG only $(392.8 \pm 105 \cdot 2 \mathrm{ng} /$ testis $/ 4 \mathrm{~h}$; Text-fig. $5 \mathrm{~b})$. However, the injection of $2 \mathrm{mg}$ tamoxifen at the same time as hCG had no effect on the in-vitro steroidogenic response at 2 $h$. The basal and stimulated secretion of testosterone by testes from rats given tamoxifen before hCG and those given tamoxifen at the same time as hCG were similar at 2 and $12 \mathrm{~h}$ but significantly higher than those in the hCG group $(P<0.05 ;$ Text-fig. 5b). The testes were refractory to further hCG stimulation from $12 \mathrm{~h}$ to 3 days. Stimulated levels returned to normal at 4 and 5 days but basal secretion of testosterone was higher than in controls at these times.

Concomitant administration of $3 \mu \mathrm{g}$ tamoxifen with $100 \mathrm{i} . \mathrm{u}$. hCG also failed to prevent refractoriness between $12 \mathrm{~h}$ and 3 days. Basal and stimulated testosterone production at $2 \mathrm{~h}$


Time after injection

Text-fig. 4. The effect of tamoxifen ( $\mathrm{Tx} ; \mathrm{a}, 2 \mathrm{mg} ; \mathrm{b}, 3 \mu \mathrm{g}$ ) on the in-vitro steroidogenic response of rat testes. Each point is the mean of 5 animals. $\mathrm{S}=$ stimulated; $\mathrm{B}=$ basal. 



Time after injection

Text-fig. 5. The effect of $2 \mathrm{mg}$ tamoxifen on the in-vitro steroidogenic activity in rat testes after a single injection of 100 i.u. hCG. (a) The pattern seen after hCG only; (b) effect of tamoxifen administered $24 \mathrm{~h}$ before ( $\mathrm{Tx}+\mathrm{hCG}$ ) or at the same time as (hCG + Tx) hCG. $\mathrm{S}=$ stimulated $\mathrm{B}=$ basal. The refractory period is indicated by the hatched bar.

$(417.6 \pm 46 \cdot 0$ and $571 \cdot 2 \pm 85.4 \mathrm{ng} /$ testis/4 h; Text-fig. $6 \mathrm{~b})$ were not significantly different from those of hCG-treated control testes $(379.2 \pm 33.6$ and $613.6 \pm 82.8 \mathrm{ng} /$ testis $/ 4 \mathrm{~h}$; Text-fig. $6 \mathrm{a})$. The fall in basal and stimulated testosterone production after $2 \mathrm{~h}$ in vitro by testes from the rats given tamoxifen prior to hCG was similar to that observed after the higher dose of tamoxifen. Basal secretion increased after 2 days and showed a peak at 4 days $(103.2 \pm 13.9 \mathrm{ng} /$ testis $/ 4 \mathrm{~h})$ returning to normal at 5 days $(53 \cdot 6 \pm 3 \cdot 6 \mathrm{ng} /$ testis $/ 4 \mathrm{~h})$. The steroidogenic capacity, as shown by stimulated levels, increased after 2 days, reached control levels at 4 days $(337.6 \pm 20.4 \mathrm{ng} / \mathrm{testis} / 4 \mathrm{~h})$ and was significantly greater than that of controls at 5 days $(222 \cdot 4 \pm 9.9 \mathrm{ng} /$ testis/4 h; Text-fig. $6 \mathrm{~b})$.
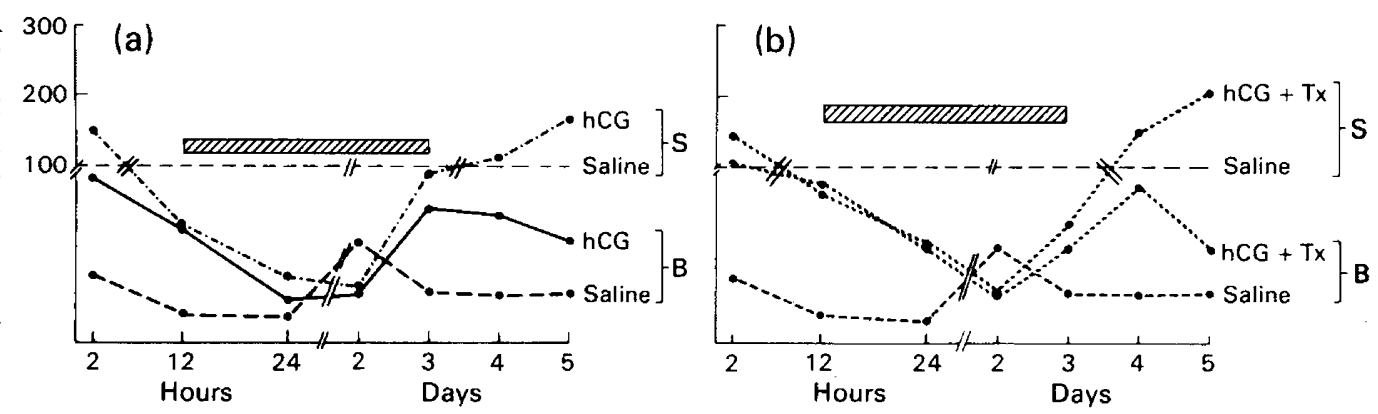

Time after injection

Text-fig. 6. Effect of $3 \mu \mathrm{g}$ tamoxifen on the in-vitro testosterone production by testes of rats injected with 100 i.u. hCG or saline. (a) The pattern seen after hCG only; (b) effect of tamoxifen administered at the same time as hCG (hCG $+\mathrm{Tx}$ ). Each point represents the mean value for 5 testes. $S=$ stimulated; $B=$ basal. The refractory period is indicated by the hatched bar.

\section{Discussion}

The results of this study confirm previous observations that the serum testosterone response to a large injection of hCG is biphasic, the two peaks being separated by a nadir of approximately $48 \mathrm{~h}$ (Haour \& Saez, 1977; Hodgson \& de Kretser, 1982). The present results demonstrate that this 48 -h period corresponds to the time when the testes from hCG treated rats are refractory to further stimulation in vitro. However, the second peak occurs when refractoriness to in-vitro stimulation is still present but corresponds to the time at which a significant rise in the basal levels of testosterone production occurs in vitro. Nevertheless, in-vitro basal testosterone production by testes stimulated 
by hCG is not different from basal levels in saline-treated rats at 24 and $48 \mathrm{~h}$ after treatment, a fact neglected by other investigators. The period of refractoriness to in-vitro stimulation was induced in this study by a s.c. injection of 100 i.u. hCG and is similar to the results obtained by Hsueh, Dufau \& Catt (1977) but differs from those of Tsuruhara et al. (1977) and Cigorraga et al. (1980) who could not induce this phenomenon by subcutaneous administration of hCG.

It has been postulated by Cigorraga et al. (1980) that this refractoriness is induced by the rise in intratesticular oestradiol levels that occur shortly after a large injection of hCG. The rise in oestradiol in turn was postulated to cause a decrease in the enzymic activity of the 17-20 desmolase and $17 \alpha$-hydroxylase, thereby reducing androgen production and increasing $17 \alpha$-hydroxyprogesterone and progesterone levels. The results in the present study do not support this hypothesis, because administration of oestradiol benzoate, which significantly elevates testicular oestradiol levels, did not result in an extension of the refractory period demonstrated in vitro and in vivo by the failure to modify the biphasic serum testosterone response. It is possible, although unlikely, that the raised intratesticular oestradiol levels may still not be as great as those achieved intracellularly in Leydig cells after hCG stimulation. However, the results for two doses of tamoxifen do not confirm the results of similar studies by Cigorraga et al. (1980) who reported that this antioestrogen reversed the refractoriness after a large injection of hCG. Although one of the tamoxifen treatments which we used was identical to that used by Cigorraga et al. (1980) their experimental design used a smaller dose of hCG (10 i.u.) given intravenously and the assessment of testosterone production was performed on isolated Leydig cells rather than decapsulated testes. Whether such minor differences can account for the conflicting results requires further exploration, although other studies involving tamoxifen (Brinkmann, Leemborg \& van der Molen, 1981; Brinkmann, Leemborg, Rommerts \& van der Molen, 1982) and the anti-oestrogen CI-628 (Melner \& Abney, 1980b) have also been unable to confirm the findings of Cigorraga et al. (1980). The only evidence from the study to support a role for oestradiol in the control of Leydig cell steroidogenesis is the stimulation of in-vitro testosterone production demonstrated at $2 \mathrm{~h}$ in those rats which received tamoxifen $24 \mathrm{~h}$ before hCG. The enhanced production of testosterone may reflect the abolition of a tonic inhibitory influence mediated via the oestradiol receptor on Leydig cells (Brinkmann, Mulder, LamersStahlhofen, Mechielsen \& van der Molen, 1972; Brinkmann et al., 1981).

The experiments that have demonstrated that oestradiol suppresses the activity of 17-20 desmolase and $17 \alpha$-hydroxylase used chronic administration of oestradiol in normal or cryptorchid BALB/C mice (Samuels et al., 1964; Samuels, Uchikawa, Zian-ul-Abedin \& Huseby, 1969). It has yet to be demonstrated that the acute doubling of testicular oestradiol levels in rats (Cigorraga et al., 1980) can induce the enzymic lesions described within the space of $20 \mathrm{~h}$. Since testosterone has been used as the end point in these experiments, our data make it unlikely but do not exclude the possibility of an oestradiol-independent inhibition before pregnenolone co-existing with an oestradiol-dependent microsomal lesion.

As found by others, serum testosterone levels in control rats were depressed for $36 \mathrm{~h}$ after the injection of oestradiol benzoate (Moger, 1976; Jones, Fang, Landau \& Rosenfield, 1978; Saez, Haour, Loras, Sanchez \& Cathiard, 1978; Melner \& Abney, 1980a). This decrease was probably due to the reported fall in serum LH levels (van Beurden, Mulder, de Jong \& van der Molen, 1977; Grotjan, Tcholakian \& Steinberger, 1978) since stimulation with exogenous hCG restored testosterone levels to those found in saline-treated controls stimulated by hCG. This inhibitory effect of oestradiol is also reflected in the in-vitro stimulation pattern since both the basal and hCGstimulated testosterone production were significantly lower in the oestradiol benzoate-treated rats (see Text-fig. 2b).

There are other hypotheses to explain the hCG-induced refractoriness. Sharpe \& Fraser (1980b) have shown that hCG induced the intratesticular production of an LH-RH-like material. In view of the demonstration that 17-20 desmolase and 17 $\alpha$-hydroxylase lesions can be induced by large doses of LH-RH or its agonists (Belanger et al., 1980), Sharpe, Fraser, Cooper \& Rommerts (1982) proposed that the production of the LH-RH-like material stimulated by hCG is the factor causing 
refractoriness of the testis. Even this hypothesis must be questioned in view of the study by Quinn, Dombrausky, Chen \& Payne (1981) who showed that provision of a source of cholesterol by the addition of high-density or low-density lipoproteins to the incubation medium could reverse the hCG-induced refractoriness. Quinn et al. (1981) propose that steroidogenic lesions induced after hCG stimulation result from the limited availability of substrate. This is in keeping with the finding that continued in-vivo stimulation with hCG for 7 days results in a hyper-responsiveness to hCG stimulation in vitro (Risbridger et al., 1982), presumably due to the increased capacity for substrate production by the hypertrophied Leydig cells (Hodgson, 1982).

This study was supported by grants from the National Health and Medical Research Council of Australia. We thank Dr David Robertson for his advice during the development of the radioimmunoassay for oestradiol.

\section{References}

Belanger, A., Cusan, L., Auclair, C., Seguin, C., Caron, S. \& Labrie, F. (1980) Effect of an LHRH agonist and hCG on testicular steroidogenesis in the adult rat. Biol. Reprod. 22, 1094-1101.

Brinkmann, A.O., Mulder, E., Lamers-Stahlhofen, G.J.M., Mechielsen, M.J. \& van der Molen, H.J. (1972) An oestradiol receptor in rat testis interstitial tissue. FEBS Letters 26, 301-305.

Brinkmann, A.O., Leemborg, I. \& van der Molen, H.J. (1981) hCG-induced inhibition of testicular steroidogenesis: an oestradiol-mediated process? Molec. cell. Endocr. 24, 65-72.

Brinkmann, A.O., Leemborg, I., Rommerts, F. \& van der Molen, H.J. (1982) Translocation of the testicular estradiol receptor is not an obligatory step in gonadotropin-induced inhibition of $\mathrm{C}_{17-20}$ lyase. Endocrinology 110, 1834-1836.

Cigorraga, S.B., Dufau, M.L. \& Catt, K.J. (1978) Regulation of luteinizing hormone receptors and steroidogenesis in gonadotropin-desensitized Leydig cells. J. biol. Chem. 253, 4297-4304.

Cigorraga, S.B., Sorrell, S., Bator, J., Catt, K.J. \& Dufau, M.L. (1980) Estrogen dependence of a gonadotropininduced steroidogenic lesion in rat testicular Leydig cells. J. clin. Invest. 65, 699-705.

de Kretser, D.M., Sharpe, R.M. \& Swanston, I.A. (1979) Alterations in steroidogenesis and human chorionic gonadotropin binding in the cryptorchid rat testis. Endocrinology 105, 135-138.

Forest, M.G., Lecoq, A. \& Saez, J.M. (1979) Kinetics of human chorionic gonadotropin-induced steroidogenic response of the human testis. II. Plasma 17 $\alpha-$ hydroxy progesterone, $\Lambda$-androstenedione, estrone and $17 \beta$-estradiol: evidence for the action of human chorionic gonadotropin on intermediate enzymes implicated in steroid biosynthesis. J. clin. Endocr. Metab. 49, 284-291.

Grotjan, H.E., Tcholakian, R.K. \& Steinberger, E. (1978) In-vitro responsiveness of testicular interstitial cells isolated from rats acutely treated with estradiol benzoate. Biol. Reprod. 19.902-907.

Haour, F. \& Saez, J.M. (1977) hCG-dependent regulation of gonadotropin receptor sites: negative control in testicular Leydig cells. Molec. cell. Endocr. 7, 1724.
Haour, F. \& Saez, J.M. (1978) Leydig cell responsiveness to LH-hCG stimulation: mechanisms of hCG and steroid-induced refractoriness. In Structure and Function of Gonadotropins, pp. 497-516. Ed. K. W. McKerns. Plenum Press, New York.

Hodgson, Y.M. (1982) The response of rat Leydig cells to hCG. Ph.D. thesis, Monash University.

Hodgson, Y.M. \& de Kretser, D.M. (1982) Serum testosterone response to single injections of $\mathrm{hCG}$, ovine-LH and LHRH in male rats. Int. J. Androl. 5, 81-91.

Hsueh, A.J.W., Dufau, M.L. \& Catt, K.J. (1977) Gonadotropin-induced regulation of $\mathrm{LH}$ receptors and desensitization of testicular 3'5'-cyclic AMP and testosterone responses. Proc. natn. Acad. Sci. U.S.A. 74, 592-595.

Jones, T.M., Fang, V.S., Landau, R.L. \& Rosenfield, R. (1978) Direct inhibition of Leydig cell function by estradiol. J. clin. Endocr. Metab. 47, 1368-1373.

Melner, M.H. \& Abney, T.O. (1980a) Depletion of cytoplasmic estrogen receptor in gonadotropindesensitized testes. Endocrinology 107, 1620-1626.

Melner, M.H. \& Abney, T.O. (1980b) Interactions of antiestrogens with the Leydig cell estrogen receptor: effects on cell function. Endocrinology 106, Suppl., p. 133, Abstr. 234.

Moger, W.H. (1976) Serum testosterone response to acute $\mathrm{LH}$ treatment in estradiol treated rats. Biol. Reprod. 14, 115-117.

Pomerantz, D.K. (1979) Effects of in-vivo gonadotropin treatment on estrogen levels in the testis of the immature rat. Biol. Reprod. 21, 1247-1255.

Quinn, P.G., Dombrausky, L.J., Chen, V.I. \& Payne, A.H. (1981) Serum lipoproteins increase testosterone production in hCG-desensitized Leydig cells. Endocrinology 109, 1790-1792.

Risbridger, G.P., Kerr, J.B. \& de Kretser, D.M. (1981) An evaluation of Leydig cell function and gonadotropin binding in unilateral and bilateral cryptorchidism. Evidence for local control of Leydig cell function by the seminiferous tubule. Biol. Reprod. 24, 534-540.

Risbridger, G.P., Robertson, D.M. \& de Kretser, D.M. (1982) The effects of chronic human chorionic gonadotropin treatment on Leydig cell function. Endocrinology 110, 138-145. 
Saez, J.M., Haour, F., Loras, B., Sanchez, P. \& Cathiard, A.M. (1978) Estrogen-induced Leydig cell refractoriness to gonadotropin stimulation. Endocrinology 58, $435-442$.

Samuels, L.T., Bussmann, L., Matsumoto, K. \& Huseby, R.A. (1964) The effect of diethylstilboestrol on testicular 17 $\alpha$-hydroxylase and 17-20 desmolase activities in BALB/C mice. Acta endocr., Copenh. 45, 487-497.

Samuels, L.T., Uchikawa, T., Zain-ul-Abedin, M. \& Huseby, R.A. (1969) Effect of diethylstilbestrol on enzymes of cryptorchid mouse testes of BALB/C mice. Endocrinology 85, 96-102.

Sharpe, R.M. \& Fraser, H.M. (1980a) Inhibition of maturational changes in Leydig cell function by treatment of rats with an agonist of LH-RH. $J$. Reprod. Fert. 60, 359-368.

Sharpe, R.M. \& Fraser, H.M. (1980b) hCG-stimulation of testicular LHRH-like activity. Nature, Lond. 287, 642-643.

Sharpe, R.M., Fraser, H.M., Cooper, I. \& Rommerts, F.F.G. (1982) The secretion, measurement and function of a testicular LHRH-like factor. Ann. N.Y. Acad. Sci. 103, 272-292.

Smals, A.G., Pieters, G.F., Drayer, J.I., Benraad, T.J. \& Kloppenborg, P.W. (1979) Leydig cell responsiveness to single and repeated human chorionic gonadotropin administration. J. clin. Endocr. Metab. 49, 12-14.

Tsuruhara, T., Dufau, M.L., Cigorraga, S. \& Catt, K.J. (1977) Hormonal regulation of testicular luteinizing hormone receptors. J. biol. Chem. 252, 9002-9009.

van Beurden, W.M.O., Mulder, E., de Jong, F.H. \& van der Molen, H.J. (1977) The effect of estrogens on luteinizing hormone plasma levels and on testosterone production in intact and hypophysectomized rats. Endocrinology 101, 342-349.

Received 13 September 1982 